\title{
Synthesis and physiochemical studies on binuclear $\mathrm{Cu}$ (II) complexes derived from 2,6-[(N-phenylpiperazin-1-yl)methyl]-4- substituted phenols
}

\author{
S KARTHIKEYAN, T M RAJENDIRAN*, R KANNAPPAN, \\ R MAHALAKSHMY, R VENKATESAN and P SAMBASIVA RAO \\ Department of Chemistry, Pondicherry University, RV Nagar, Kalapet, \\ Pondicherry 605 014, India \\ e-mail: tmrajen@hotmail.com
}

MS received 2 January 2001; revised 25 May 2001

\begin{abstract}
Preparation of the ligands $\mathrm{HL}^{1}=2,6-[(\mathrm{N}$-phenylpiperazin-1-yl $)$ methyl $]-p$ ethylphenol; $\quad \mathrm{HL}^{2}=2,6-[(\mathrm{N}$-phenylpiperazin-1-yl)methyl $]-p$-methoxyphenol and $\mathrm{HL}^{3}=2,6-[(\mathrm{N}$-phenylpiperazin-1-yl)methyl]-p-nitrophenol are described together with their $\mathrm{Cu}$ (II) complexes with different bridging units. The exogenous bridges incorporated into the complexes are: hydroxo $\left[\mathrm{Cu}_{2} \mathrm{~L}(\mathrm{OH})\left(\mathrm{H}_{2} \mathrm{O}\right)_{2}\right]\left(\mathrm{ClO}_{4}\right)_{2} \cdot \mathrm{H}_{2} \mathrm{O}$ $\left(\mathrm{L}^{1}=\mathbf{1 a}, \quad \mathrm{L}^{2}=\mathbf{1 b}, \mathrm{L}^{3}=\mathbf{1 c}\right)$, acetato $\left[\mathrm{Cu}_{2} \mathrm{~L}(\mathrm{OAc})_{2}\right] \mathrm{ClO}_{4} \cdot \mathrm{H}_{2} \mathrm{O} \quad\left(\mathrm{L}^{1}=\mathbf{2 a}, \mathrm{L}^{2}=\mathbf{2 b}\right.$, $\left.\mathrm{L}^{3}=\mathbf{2 c}\right)$ and nitrito $\left[\mathrm{Cu}_{2} \mathrm{~L}^{1}\left(\mathrm{NO}_{2}\right)_{2}\left(\mathrm{H}_{2} \mathrm{O}\right)_{2}\right] \mathrm{ClO}_{4} \cdot \mathrm{H}_{2} \mathrm{O} \quad\left(\mathrm{L}^{1}=\mathbf{3 a}, \mathrm{L}^{2}=\mathbf{3 b}, \mathrm{L}^{3}=\mathbf{3 c}\right)$. Complexes 1a, 1b, 1c and $\mathbf{2 a}, \mathbf{2 b}, \mathbf{2 c}$ contain bridging exogenous groups, while $\mathbf{3 a}$, $\mathbf{3 b}, \mathbf{3 c}$ possess only open $\mu$-phenolate structures. Both the ligands and complexes were characterized by spectral studies. Cyclic voltammetric investigation of these complexes revealed that the reaction process involves two successive quasireversible one-electron steps at different potentials. The first reduction potential is sensitive to electronic effects of the substituents at the aromatic ring of the ligand system, shifting to positive potentials when the substituents are replaced by more electrophilic groups. EPR studies indicate very weak interaction between the two copper atoms. Various covalency parameters have been calculated.
\end{abstract}

Keywords. Unsymmetrical ligands; dinuclear complexes; synthetic models; cyclic voltammetry.

\section{Introduction}

Studies on the geometry around the metal centre by electronic spectra and magnetic properties of the metal ions present in the active site of metallo-biomolecules are rather difficult owing to the fact that metal ions in active sites are embedded in the protein polymer backbone. Hence, design and synthesis of model compounds that mimic the physical and chemical properties of the active site present in the metallobiomolecules are very essential. Most of the binuclear copper(II) complexes are prepared from macrocyclic, side-off and end-off ligands. Complexes derived ${ }^{1}$ from side-off ligands are limited in their use as models for the $\mathrm{Cu}$ biosites as they are rigid systems with restricted coordination geometry. The $\mathrm{M}-\mathrm{M}$ distance is very small compared to the biosite and hence they are unable to support relevant exogenous bridging groups.

*For correspondence 
End-off compartment ligands are better candidates for the provision of distinct coordination environments. Many of these sub-group dinucleating ligands have been derived from 4- (or) 3,4-disubstituted phenols. Ligands of this type readily form dinuclear transition metal complexes that can coordinate with either one or two exogenous bridging units $^{2-5}$. These ligands strongly favour the formation of bimetallic species because of the enforced ideal distance between the donor sites and the presence of the endogenous bridging phenolato group. These end-off dinucleating ligands have been prepared by introducing secondary amines, in the presence of formaldehyde, activated at the 2,6positions of the para- (or) 3,4-disubstituted phenols ${ }^{6}$.

The present study describes the preparation and characterisation of a series of end-off binucleating ligands and their $\mathrm{Cu}$ (II) complexes in which the copper centres are bridged by $\mathrm{OH}, \mathrm{OAc}$ and $\mathrm{NO}_{2}$ moieties (scheme 1). The spectral, electrochemical and EPR studies of these complexes are reported and discussed here.<smiles>[R]c1cc(CN2CCN(c3ccccc3)CC2)c(O)c(CN2CCN(c3ccccc3)CC2)c1</smiles><smiles>CCCCC(C)C(=O)O[Na]</smiles>

2. $\mathrm{NaOH}$

$\mathrm{R}=\mathrm{Et}-\mathrm{HL}^{1}$

$\mathrm{R}=\mathrm{OMe}-\mathrm{HL}^{2}$

$\mathrm{R}=\mathrm{NO}_{2}-\mathrm{HL}^{3}$

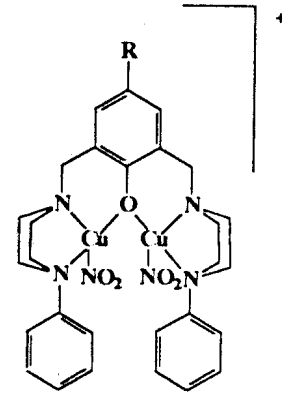

Scheme 1.
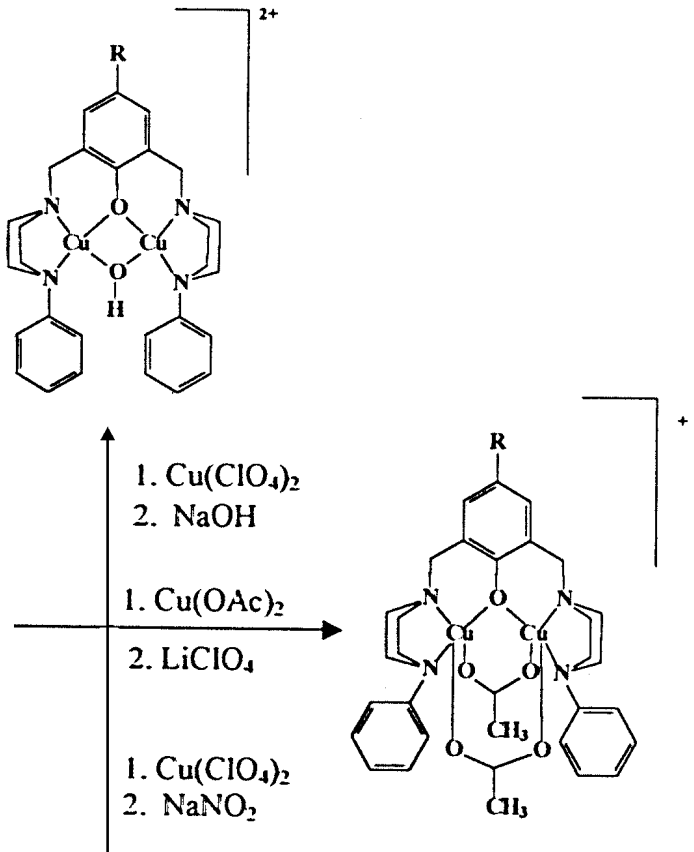


\section{Experimental}

\subsection{Physical measurements}

Elemental analyses for $\mathrm{C}, \mathrm{H}, \mathrm{N}$ and $\mathrm{Cu}$ were obtained from the Regional Sophisticated Instrumentation Centre, Indian Institute of Technology, Chennai. IR spectra were recorded on a Shimadzu FTIR $8300 / 8700$ instrument by the $\mathrm{KBr}$ pellet technique, electronic spectra on a Hitachi U-2000 spectrophotometer and ${ }^{1} \mathrm{H}$ NMR spectra recorded using $\mathrm{CDCl}_{3}$ on an EM-390, $90 \mathrm{MHz}$ NMR spectrometer. EPR spectra were recorded using a JES-TE 100 ESR spectrometer and cyclicvoltammograms were measured using BASCV-50 W electrochemical analyser in acetonitrile solution containing tetra- $n$-butyl ammoniumperchlorate (TBAP) as the supporting electrolyte. Electrospray mass spectra were recorded on a Micromass Quattro II Triple Quadrupole Mass Spectrometer. The samples were dissolved in methanol and introduced into the ESI source through a syringe pump at the rate of $5 \mu \mathrm{l}$ per min. The ESI capillary was set at $3.5 \mathrm{kV}$ and the cone voltage was $40 \mathrm{~V}$ unless stated otherwise. The spectra were collected in $6 \mathrm{~s}$ scans and the print outs are averaged spectra of 6-8 scans.

2.1a Materials: Tetrabutylammonium perchlorate used as the supporting electrolyte in electrochemical measurements was obtained from Fluka and recrystallised from methanol. Acetonitrile (HPLC grade) was obtained from SD Fine Chemicals and dried by distillation over $\mathrm{P}_{2} \mathrm{O}_{5}$ and $\mathrm{KMnO}_{4}$.

\subsection{Preparation of the ligands}

The ligands were synthesized by a modified procedure ${ }^{7}$ based on Mannich base reaction of $p$-substituted phenols, formaldehyde and N-phenylpiperazine.

2.2a Preparation of 2,6[(N-phenylpiperazin-1-yl)methyl $]$-p-ethylphenol $\left(H L^{1}\right): 6 \cdot 108 \mathrm{~g}$ $(0.05 \mathrm{~mol})$ of $p$-ethylphenol was completely dissolved in $100 \mathrm{ml}$ of distilled ethanol. Then $15.3 \mathrm{ml}(0.1 \mathrm{~mol})$ of $\mathrm{N}$-phenylpiperazine, followed by $12.5 \mathrm{ml}$ of formaldehyde, was added drop by drop with constant stirring. The resulting solution was stirred at room temperature for half an hour and refluxed for $24 \mathrm{~h} .2 .5 \mathrm{ml}$ of formaldehyde was added at approximately 8-hour intervals. After refluxing, ethanol was removed by distillation under vacuum. The precipitate obtained was collected and dried. The product was recrystallized from ethanol.

m.p. $=167^{\circ} \mathrm{C}$; Yield: $80 \%$; IR (KBr disc): $3390 \mathrm{~cm}^{-1}(b r, \mathrm{OH}), 1600 \mathrm{~cm}^{-1}(\mathrm{~N}-\mathrm{Ph})$, $1600 \mathrm{~cm}^{-1}$ (aromatic), $1458 \mathrm{~cm}^{-1}\left(\mathrm{CH}_{3}\right) ;{ }^{1} \mathrm{H} \mathrm{NMR}$ in $\mathrm{CDCl}_{3}, \delta \mathrm{ppm}: 1 \cdot 2\left(t, 3 \mathrm{H}, \mathrm{CH}_{3}\right)$, $2 \cdot 65\left(q, 2 \mathrm{H}, \mathrm{CH}_{2}-\mathrm{Ph}\right), 2 \cdot 7-3 \cdot 2\left(d d, 16 \mathrm{H} \mathrm{N}-\mathrm{CH}_{2}\right), 3 \cdot 7\left(s, 4 \mathrm{H}\right.$, benzyl $\left.\mathrm{CH}_{2}\right), 6 \cdot 9-7 \cdot 3(m$, $12 \mathrm{H}, \mathrm{ArH})$.

The ligands $\mathrm{HL}^{2}$ and $\mathrm{HL}^{3}$ were prepared by adopting the same procedure as that used for $\mathrm{HL}^{1}$.

2.2b Preparation of 2,6[(N-phenylpiperazin-1-yl)methyl]-p-methoxyphenol $\left(\mathrm{HL}^{2}\right)$ : m.p. $=183^{\circ} \mathrm{C}$; Yield: $80 \%$; IR (KBr disc): $3435 \mathrm{~cm}^{-1}(b r, \mathrm{OH}), 1600 \mathrm{~cm}^{-1}(\mathrm{~N}-\mathrm{Ph})$, $1600 \mathrm{~cm}^{-1}$ (aromatic), $1224 \mathrm{~cm}^{-1}\left(\mathrm{CH}_{3}\right) ;{ }^{1} \mathrm{H} \mathrm{NMR}$ in $\mathrm{CDCl}_{3} \delta \mathrm{ppm}: 2 \cdot 8-3 \cdot 3(d d, 16 \mathrm{H}, \mathrm{N}-$ $\left.\mathrm{CH}_{2}\right), 3 \cdot 7\left(s, 4 \mathrm{H}, \mathrm{CH}_{2}\right), 3 \cdot 8\left(s, 3 \mathrm{H}, \mathrm{OCH}_{3}\right), 6 \cdot 9(\mathrm{~m}, 10 \mathrm{H}, \mathrm{Ph})$ and $7 \cdot 3(s, 2 \mathrm{H}, \mathrm{ArH})$. 
2.2c Preparation of 2,6[(N-phenyl piperazin-1yl)methyl]-p-nitrophenol $\left(\mathrm{HL}^{3}\right)$ : Yield: 80\%; IR (KBr disc): $3440 \mathrm{~cm}^{-1}$ ( $\left.b r, \mathrm{OH}\right), 1600 \mathrm{~cm}^{-1}$ (N-Ph), $1600 \mathrm{~cm}^{-1}$ (aromatic), $1498 \mathrm{~cm}^{-1}\left(\mathrm{NO}_{2}\right){ }^{1} \mathrm{H} \mathrm{NMR}$ in $\mathrm{CDCl}_{3} \delta \mathrm{ppm}: 2 \cdot 8-3 \cdot 3\left(d d, 16 \mathrm{H}, \mathrm{N}-\mathrm{CH}_{2}\right), 3 \cdot 7\left(s, 4 \mathrm{H}, \mathrm{CH}_{2}\right)$, 6.9-7.0 ( $m, 12 \mathrm{H} \mathrm{ArH})$.

\subsection{Preparation of the complexes}

2.3a Preparation of the hydroxo bridged complexes: (i) $\left[\mathrm{Cu}_{2} \mathrm{~L}^{l}(\mathrm{OH})\right.$ $\left(\mathrm{H}_{2} \mathrm{O}\right)_{2} \mathrm{~J}\left(\mathrm{ClO}_{4}\right)_{2} \cdot \mathrm{H}_{2} \mathrm{O}(\mathbf{l a})$ - To the methanolic solution of the ligand (1 mmol), sodium hydroxide ( $1 \mathrm{mmol}$ ) was added, followed by copper(II) perchlorate hexahydrate $(2 \mathrm{mmol})$ dissolved in methanol. The resulting greenish blue solution was refluxed for one hour and then filtered. A green precipitate was obtained on evaporation at room temperature for several days, which yielded a dark green compound which was recrystallized from aqueous methanol. (Found: $\mathrm{C}=41.52, \mathrm{H}=5.05, \mathrm{~N}=6.41, \mathrm{Cu}=14.32 \%$. Cal. for $\mathrm{C}_{30} \mathrm{H}_{42} \mathrm{Cl}_{2} \mathrm{~N}_{4} \mathrm{O}_{12} \mathrm{Cu}_{2} . \mathrm{H}_{2} \mathrm{O}: \mathrm{C}=41 \cdot 57, \mathrm{H}=5 \cdot 08, \mathrm{~N}=6 \cdot 46, \mathrm{Cu}=14 \cdot 67 \%$.)

(ii) $\left[\mathrm{Cu}_{2} \mathrm{~L}^{2}(\mathrm{OH})\left(\mathrm{H}_{2} \mathrm{O}\right)_{2}\right]\left(\mathrm{ClO}_{4}\right)_{2} \cdot \mathrm{H}_{2} \mathrm{O} \quad(\mathbf{l b}), \quad\left[\mathrm{Cu}_{2} \mathrm{~L}^{3}(\mathrm{OH})\left(\mathrm{H}_{2} \mathrm{O}\right)_{2}\right]\left(\mathrm{ClO}_{4}\right)_{2} . \mathrm{H}_{2} \mathrm{O} \quad(\mathbf{l c})-$ These complexes were prepared by the same procedure as $1 \mathrm{a}$ using $\mathrm{HL}^{2}$ or $\mathrm{HL}^{3}$ instead of

$\mathrm{HL}^{1}$. (Found: $\mathrm{C}=40.01, \quad \mathrm{H}=4.80, \quad \mathrm{~N}=6.47, \quad \mathrm{Cu}=14.60 \%$. Cal. for $\mathrm{C}_{29} \mathrm{H}_{40} \mathrm{Cl}_{2} \mathrm{Cu}_{2} \mathrm{~N}_{4} \mathrm{O}_{13} \cdot \mathrm{H}_{2} \mathrm{O} ; \quad \mathrm{C}=40 \cdot 09, \quad \mathrm{H}=4.83, \quad \mathrm{~N}=6.45, \quad \mathrm{Cu}=14.64 \% ; \quad$ Found: $\mathrm{C}=37.99 \%, \quad \mathrm{H}=4.39, \quad \mathrm{~N}=7 \cdot 86, \quad \mathrm{Cu}=14 \cdot 12 ; \quad$ Cal. for $\mathrm{C}_{28} \mathrm{H}_{37} \mathrm{Cl}_{2} \mathrm{Cu}_{2} \mathrm{~N}_{5} \mathrm{O}_{14} \cdot \mathrm{H}_{2} \mathrm{O}$ : $\mathrm{C}=38 \cdot 05, \mathrm{H}=4 \cdot 41, \mathrm{~N}=7 \cdot 92, \mathrm{Cu}=14 \cdot 39 \%)$.

2.3b Preparation of the bis acetato bridged complexes: (i) $\left[\mathrm{Cu}_{2} \mathrm{~L}^{l}(\mathrm{OAc})_{2}\right] \mathrm{ClO}_{4} \cdot \mathrm{H}_{2} \mathrm{O}$ (2a) - Copper(II) acetate monohydrate $(0.002 \mathrm{~mol})$ was dissolved in methanol $(75 \mathrm{ml})$. Addition of the methanolic solution of the ligand $(0.001 \mathrm{~mol})$ and $(0.002 \mathrm{~mol})$ of lithium perchlorate to it, led to the formation of a dark green solution. The mixture was refluxed for one hour and filtered. The filtrate was allowed slowly to evaporate at room temperature. A dark green solid was obtained, washed with methanol and left to dry in air at room temperature. (Found: $\mathrm{C}=49 \cdot 12, \mathrm{H}=5 \cdot 40, \mathrm{~N}=6.71, \mathrm{Cu}=15 \cdot 20 \%$; Cal. for $\left.\mathrm{C}_{34} \mathrm{H}_{43} \mathrm{Cl} \mathrm{Cu} \mathrm{Cu}_{4} \mathrm{O}_{9} \cdot \mathrm{H}_{2} \mathrm{O}: \mathrm{C}=49 \cdot 06, \mathrm{H}=5 \cdot 41, \mathrm{~N}=6 \cdot 73, \mathrm{Cu}=15 \cdot 28 \%\right)$.

(ii) $\left[\mathrm{Cu}_{2} \mathrm{~L}^{2}(\mathrm{OAc})_{2}\right] \mathrm{ClO}_{4} \cdot \mathrm{H}_{2} \mathrm{O}(\mathbf{2 b}),\left[\mathrm{Cu}_{2} \mathrm{~L}^{3}(\mathrm{OAc})_{2}\right] \mathrm{ClO}_{4} \cdot \mathrm{H}_{2} \mathrm{O}(2 \mathrm{c})$ - These complexes were prepared by the same procedure as $\mathbf{2 a}$ using $\mathrm{HL}^{2}$ or $\mathrm{HL}^{3}$ instead of $\mathrm{HL}^{1}$. (Found: $\mathrm{C}=47.59, \quad \mathrm{H}=4.98, \quad \mathrm{~N}=6.69, \quad \mathrm{Cu}=15.21 \%$; Cal. for $\mathrm{C}_{33} \mathrm{H}_{41} \mathrm{ClCu}_{2} \mathrm{~N}_{4} \mathrm{O}_{10} \cdot \mathrm{H}_{2} \mathrm{O}$ : $\mathrm{C}=47 \cdot 50, \mathrm{H}=5 \cdot 15, \mathrm{~N}=6 \cdot 71, \mathrm{Cu}=15 \cdot 24 \%$; Found: $\mathrm{C}=45 \cdot 21, \mathrm{H}=4 \cdot 71, \mathrm{~N}=8 \cdot 12$, $\mathrm{Cu}=14.81 \%$; Cal. for $\mathrm{C}_{32} \mathrm{H}_{38} \mathrm{ClCu}_{2} \mathrm{~N}_{5} \mathrm{O}_{11} \cdot \mathrm{H}_{2} \mathrm{O}: \mathrm{C}=45 \cdot 25, \mathrm{H}=4 \cdot 71, \mathrm{~N}=8 \cdot 24, \mathrm{Cu}=$ $14.97 \%$.)

2.3c Preparation of the bis nitrito bridged complexes: (i) $\left[\mathrm{Cu}_{2} \mathrm{~L}^{\mathrm{l}}\left(\mathrm{NO}_{2}\right)_{2}\left(\mathrm{H}_{2} \mathrm{O}\right)_{2}\right] \mathrm{ClO}_{4}$. $\mathrm{H}_{2} \mathrm{O}(3 \mathrm{a})$ - A solution of sodium nitrite $(0.003 \mathrm{~mol})$ dissolved in methanol $(75 \mathrm{ml})$ was added to the methanolic solution containing the ligand $(0.001 \mathrm{~mol})$ and copper (II) perchlorate hexahydrate $(0.002 \mathrm{~mol})$. The resulting bluish green solution was refluxed for $4 \mathrm{~h}$ and filtered. Upon concentration of this solution green black crystals were obtained, which were recrystallised from aqueous methanol. (Found: $\mathrm{C}=42.68, \mathrm{H}=5 \cdot 02$, $\mathrm{N}=9 \cdot 80, \mathrm{Cu}=15 \cdot 01 \%$; Cal. for $\mathrm{C}_{30} \mathrm{H}_{41} \mathrm{ClCu}_{2} \mathrm{~N}_{6} \mathrm{O}_{11} \cdot \mathrm{H}_{2} \mathrm{O}: \mathrm{C}=42 \cdot 77, \mathrm{H}=5 \cdot 10, \mathrm{~N}=9 \cdot 98$, $\mathrm{Cu}=15 \cdot 10 \%$.)

(ii) $\left[\mathrm{Cu}_{2} \mathrm{~L}^{2}\left(\mathrm{NO}_{2}\right)_{2}\left(\mathrm{H}_{2} \mathrm{O}\right)_{2}\right] \mathrm{ClO}_{4} \cdot \mathrm{H}_{2} \mathrm{O} \quad(3 \mathrm{~b}), \quad\left[\mathrm{Cu}_{2} \mathrm{~L}^{3}\left(\mathrm{NO}_{2}\right)_{2}\left(\mathrm{H}_{2} \mathrm{O}\right)_{2}\right] \mathrm{ClO}_{4} \cdot \mathrm{H}_{2} \mathrm{O} \quad(3 \mathrm{c})-$ These complexes were prepared by the same procedure as $3 \mathbf{a}$ using $\mathrm{HL}^{2}$ or $\mathrm{HL}^{3}$ instead of $\mathrm{HL}^{1}$. (Found: $\mathrm{C}=41 \cdot 23, \mathrm{H}=4 \cdot 61, \mathrm{~N}=9 \cdot 82, \mathrm{Cu}=15 \cdot 01 \% \mathrm{Cal}$. for $\mathrm{C}_{29} \mathrm{H}_{39} \mathrm{ClCu}_{2} \mathrm{~N}_{6} \mathrm{O}_{12}$. 
$\mathrm{H}_{2} \mathrm{O}: \mathrm{C}=41 \cdot 25, \mathrm{H}=4 \cdot 80, \quad \mathrm{~N}=9.95, \quad \mathrm{Cu}=15.06 \% ; \quad$ Found: $\mathrm{C}=39 \cdot 01, \mathrm{H}=4 \cdot 36$, $\mathrm{N}=11.20, \quad \mathrm{Cu}=14.63 \% ; \quad \mathrm{Cal}$. for $\mathrm{C}_{28} \mathrm{H}_{36} \mathrm{ClCu}_{2} \mathrm{~N}_{7} \mathrm{O}_{13} \cdot \mathrm{H}_{2} \mathrm{O}: \quad \mathrm{C}=39 \cdot 13, \quad \mathrm{H}=4 \cdot 42$, $\mathrm{N}=11 \cdot 41, \mathrm{Cu}=14 \cdot 80 \%)$.

\section{Results and discussion}

\subsection{Synthesis and characterization}

Complexes 1a, 1b and 1c were prepared by using the ethanolic solution of ligand and copper(II) perchlorate hexahydrate 1:2 molar ratio in the presence of sodium hydroxide. The bis acetato complexes $\mathbf{2 a}, \mathbf{2} \mathbf{b}$ and $\mathbf{2 c}$ were synthesized from the reaction of the ligands with copper(II) acetate monohydrate and lithium perchlorate. The dinitrito $\mathbf{3 a}, \mathbf{3 b}$ and 3c complexes were obtained using a 1:2 molar ratio of the ligand and copper perchlorate in the presence of sodium nitrite in aqueous ethanol.

Spectroscopic techniques were used to elucidate the structure of the complexes. The $\mathrm{OH}$-bridged complexes exhibit a broad IR band around $3480-3600 \mathrm{~cm}^{-1}$ due to the $\mathrm{OH}$ stretching ${ }^{8,9}$. The perchlorate salts show a strong band near $1100 \mathrm{~cm}^{-1}$ and sharp band around $620-630 \mathrm{~cm}^{-1}$ indicative of the uncoordinated perchlorate anion ${ }^{10,11}$. The bis acetato bridged complexes showed ${ }^{12}$ strong $\mathrm{v}(\mathrm{COO})$ bands around 1485 and $1583 \mathrm{~cm}^{-1}$. IR bands due to the nitrite groups were observed around $1240-1495 \mathrm{~cm}^{-1}$ which on comparison to the one published ${ }^{13}$ would suggest a monodentate O-bonded mode for the nitrite groups.

The electronic spectra of these complexes in methanol show a low intensity band in the region $600-800 \mathrm{~nm}$ indicative of pyramidal geometry ${ }^{14}$, a medium intensity band occurring between 360 and $480 \mathrm{~nm}$ due to charge transfer from phenolato to $\mathrm{Cu}(\mathrm{II}){ }^{15}$. An intense absorption band around $280-330 \mathrm{~nm}$ has also been observed which probably arises due to the ligand-to-ligand charge transfer transition.

\subsection{Redox properties}

The electrochemical properties of the complexes were studied by cyclic voltammetry The cyclic voltammetric measurements were performed in dry acetonitrile. TBAP was used as supporting electrolyte. The solutions were deoxygenated by purging dry nitrogen for 10 min before taking measurements. A three-electrode cell configuration with a platinum disc as the working, a platinum rod as the counter and saturated $\mathrm{LiCl}-\mathrm{Ag} / \mathrm{AgCl}$ as the reference electrodes were employed.

All the complexes undergo two one-electron reduction and oxidation at two different potentials. Figure 1 shows the cyclic voltammogram of $\mathbf{1 b}$. The electrochemical data are summarized in table 1.

Electrochemical behaviour in the negative potential range is sensitive to the electron inductive $(+I$ (or) $-I$ ) nature of the substituents at the para position of the benzene rings. It has been observed that (i) the $E_{\mathrm{pc}}$ and $E_{\mathrm{pa}}$ values change with the scan rate. (ii) the $\Delta E p$ increases with increase of scan rate and was found to be more than $60 \mathrm{mV}$ and (iii) the cathodic (IC) and anodic (Ia) peak currents were not equal. This indicates the quasireversible nature of the electron transfer process. Coulometric experiments indicated that each of the couples was involved in a one-electron transfer process. Therefore it is reasonable to assign the two waves to successive one-electron reactions at the metal centres. 


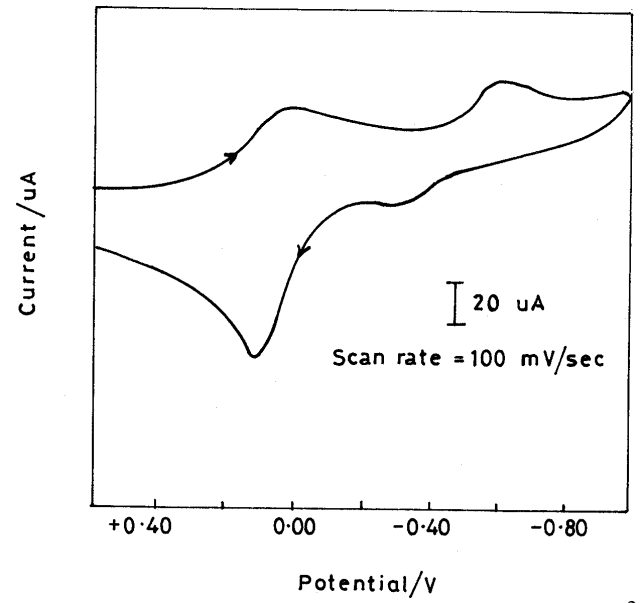

Figure 1. Cyclic voltammogram of $\left[\mathrm{Cu}_{2} \mathrm{~L}^{2}(\mathrm{OH})\left(\mathrm{H}_{2} \mathrm{O}\right)_{2}\right]\left(\mathrm{ClO}_{4}\right)_{2} \cdot \mathrm{H}_{2} \mathrm{O}$ (1) $\mathrm{CH}_{3} \mathrm{CN}$.

Table 1. Electrochemical data for complexes with their conproportionation constants $\left(K_{\text {con }}\right)$ and conductivity data.

\begin{tabular}{|c|c|c|c|c|c|}
\hline Complex ${ }^{a}$ & $E_{1 / 2}^{1}\left(\Delta E_{p}\right)^{\mathrm{b}}$ & $E_{1 / 2}^{2}\left(\Delta E_{p}\right)$ & $K_{\text {con }}$ & $\begin{array}{c}\text { Equivalent } \\
\text { conductance } \\
\left(\mathrm{ohm} \mathrm{cm}^{2} \mathrm{~mol}^{-1}\right)\end{array}$ & $\begin{array}{l}\text { Type of } \\
\text { electrolyte }\end{array}$ \\
\hline $1 \mathbf{a}$ & $+0 \cdot 19(+0 \cdot 46)$ & $-0 \cdot 28(+0 \cdot 20)$ & $8.96 \times 10^{7}$ & 180 & $1: 2$ \\
\hline $1 \mathrm{~b}$ & $-0.01(+0.26)$ & $-1.22(+0.38)$ & $2.97 \times 10^{20}$ & 180 & $1: 2$ \\
\hline 1c & $+0.22(+0.52)$ & $-0.42(+0.38)$ & $6.74 \times 10^{10}$ & 200 & $1: 2$ \\
\hline $\mathbf{2 a}$ & $+0 \cdot 11(+0 \cdot 18)$ & $-0.57(+0.38)$ & $3.20 \times 10^{11}$ & 110 & $1: 1$ \\
\hline $2 b$ & $+0.23(+0.30)$ & $-0.82(+0.54)$ & $5.80 \times 10^{17}$ & 110 & $1: 1$ \\
\hline $3 \mathbf{a}$ & $+0.14(+0.22)$ & $-0.66(+0 \cdot 70)$ & $3.40 \times 10^{13}$ & 100 & $1: 1$ \\
\hline $3 b$ & $+0.21(+0.34)$ & $-0.25(+0.70)$ & $6.60 \times 10^{7}$ & 100 & $1: 1$ \\
\hline $3 c$ & $-0 \cdot 67(+0 \cdot 06)$ & $-1 \cdot 14(+0 \cdot 08)$ & $8.90 \times 10^{7}$ & 100 & $1: 1$ \\
\hline
\end{tabular}

${ }^{\mathrm{a}} 1 \mathrm{mmol}$ of the complexes in $\mathrm{CH}_{3} \mathrm{CN}(0 \cdot 1 \mathrm{M}$ TBAP $)$ was used; ${ }^{\mathrm{b}}\left(\Delta E_{\mathrm{p}}\right)=E_{\mathrm{Pc}}-E_{\mathrm{Pa}}$; $E_{1 / 2}=E_{\mathrm{Pc}}+E_{\mathrm{Pa}} / 2 ; \log K_{\mathrm{con}}=E_{1 / 2}^{1}-E_{1 / 2}^{2} / 0 \cdot 0591$.

$$
\mathrm{Cu}^{\mathrm{II}} \mathrm{Cu}^{\mathrm{II}} \stackrel{E_{1}{ }^{\mathrm{f}}}{\rightleftharpoons} \mathrm{Cu}^{\mathrm{II}} \mathrm{Cu}^{\mathrm{I}} \stackrel{E_{2}{ }^{\mathrm{f}}}{\rightleftharpoons} \mathrm{Cu}^{\mathrm{I}} \mathrm{Cu}^{\mathrm{I}} .
$$

In table 1 , it is important to note that the replacement of a relatively electron-releasing (ethyl) group by an electron-withdrawing $\mathrm{NO}_{2}$ group shifts the first reduction to more negative potentials. A similar trend has been observed by Lacroix et $a l^{16}$ and Sujatha et $a l^{17}$.

The stability of the mixed valent complexes is expressed by the conproportionation constant $K_{\text {con }}$ for the following equilibrium,

$$
\left[\mathrm{Cu}^{\mathrm{II}} \mathrm{Cu}^{\mathrm{II}}\right]+\left[\mathrm{Cu}^{\mathrm{I}} \mathrm{Cu}^{\mathrm{I}}\right] \rightleftharpoons 2\left[\mathrm{Cu}^{\mathrm{I}} \mathrm{Cu}^{\mathrm{II}}\right] .
$$


The $K_{\text {con }}$ values of the complexes have been determined by electrochemically using the equation, $\log K_{\text {con }}=E_{1 / 2} / 0.059$ (at $25^{\circ} \mathrm{C}$ ), where $E_{1 / 2}=E_{1 / 2}^{1}-E_{1 / 2}^{2}$. From table 1 , it is evident that the large $K_{\text {con }}$ values indicate that the addition of a second electron is more difficult than that of the first electron, and the $\mathrm{Cu}(\mathrm{II})-\mathrm{Cu}(\mathrm{I})$ mixed valence species is stable with respect to conproportionation. This situation is more common and is often observed in several binuclear systems ${ }^{18-20}$. Coulometric experiments conducted at $-1.0 \mathrm{~V}$ which confirm the consumption of 2 electrons per molecule.

\subsection{Conductivity studies}

Conductances of the complexes have been studied using methanol as solvent. The type of electrolyte is $1: 1$ for acetate and nitrite and 1:2 for hydroxo complexes. The conductance data are given in table 1 .

\subsection{Electron paramagnetic resonance}

EPR studies have been carried out only on powder samples as we could not get wellshaped single crystals suitable for EPR studies. Samples were nicely powdered and the spectra were recorded in a quartz tube to avoid lines from impurities like $\mathrm{Fe}^{3+}$ and $\mathrm{Mn}^{2+}$.

Complex 1a gave an axially symmetric EPR spectrum with $g_{\|}=2 \cdot 208, A_{\|}=18.2 \mathrm{mT}$, $g_{\perp}=2 \cdot 115$ and $A_{\perp}=3.4 \mathrm{mT}$. EPR spectra of complexes $\mathbf{1 b}$ and $\mathbf{1 c}$ are shown in figure 2 and the spin Hamiltonian parameters calculated from the spectra are given in table 2. For these three complexes (1a, $\mathbf{1 b}$ and $\mathbf{1 c})$ the parallel values are close, whereas the perpendicular values differ slightly. The complex $\mathbf{1 b}$ behaves slightly different compared to 1a and 1c. The hyperfine values indicate very weak coupling between the two copper ions and one can say that the unpaired electron is mainly localized on one copper ion.

We have also recorded the EPR spectra for complexes $\mathbf{2 a}, \mathbf{2 b}$ and $\mathbf{2 c}$. The spin Hamiltonian parameters have been calculated and are also given in table 2 . Here also complexes 2a and 2c have similar $g$ and $A$ values where as complex $\mathbf{2 b}$ has slightly different values, especially the $A_{\perp}$ value. The EPR spectra for the complex $\mathbf{2 c}$ are shown in figure 3. The complexes $\mathbf{3 a}, \mathbf{3 b}$ and $\mathbf{3 c}$ have two nitrite groups as compensating ions.

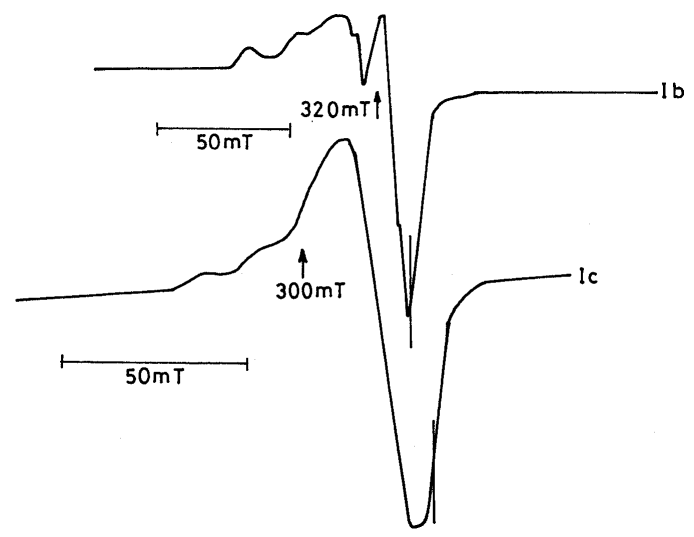

Figure 2. EPR spectrum of hydroxo-bridged $\left[\mathrm{Cu}_{2} \mathrm{~L}^{2}(\mathrm{OH})\left(\mathrm{H}_{2} \mathrm{O}\right)_{2}\right]\left(\mathrm{ClO}_{4}\right)_{2} \cdot \mathrm{H}_{2} \mathrm{O}(\mathbf{1 b})$ and hydroxo-bridged $\left[\mathrm{Cu}_{2} \mathrm{~L}^{3}(\mathrm{OH})\left(\mathrm{H}_{2} \mathrm{O}\right)_{2}\right]\left(\mathrm{ClO}_{4}\right)_{2} \cdot \mathrm{H}_{2} \mathrm{O}(\mathbf{1 c})$. 
Table 2. EPR spectral data for $\mathrm{Cu}(\mathrm{II})$ complexes.

\begin{tabular}{lcccc}
\hline Complexes & $g_{\|}$ & $g_{\perp}$ & $A_{\|}(\mathrm{mT})$ & $A_{\perp}(\mathrm{mT})$ \\
\hline 1a & $2 \cdot 208$ & $2 \cdot 115$ & $18 \cdot 2$ & $3 \cdot 4$ \\
1b & $2 \cdot 275$ & $2 \cdot 074$ & $18 \cdot 8$ & $2 \cdot 1$ \\
1c & $2 \cdot 216$ & $2 \cdot 131$ & $17 \cdot 9$ & $4 \cdot 3$ \\
2a & $2 \cdot 215$ & $2 \cdot 145$ & $18 \cdot 2$ & $4 \cdot 7$ \\
2b & $2 \cdot 225$ & $2 \cdot 100$ & $19 \cdot 0$ & $3 \cdot 1$ \\
2c & $2 \cdot 208$ & $2 \cdot 115$ & $19 \cdot 0$ & $4 \cdot 3$ \\
3a & $2 \cdot 217$ & $2 \cdot 089$ & $18 \cdot 9$ & $2 \cdot 9$ \\
3b & $2 \cdot 231$ & $2 \cdot 095$ & $19 \cdot 3$ & $3 \cdot 1$ \\
3c & $2 \cdot 210$ & $2 \cdot 112$ & $19 \cdot 6$ & $4 \cdot 1$ \\
\hline
\end{tabular}

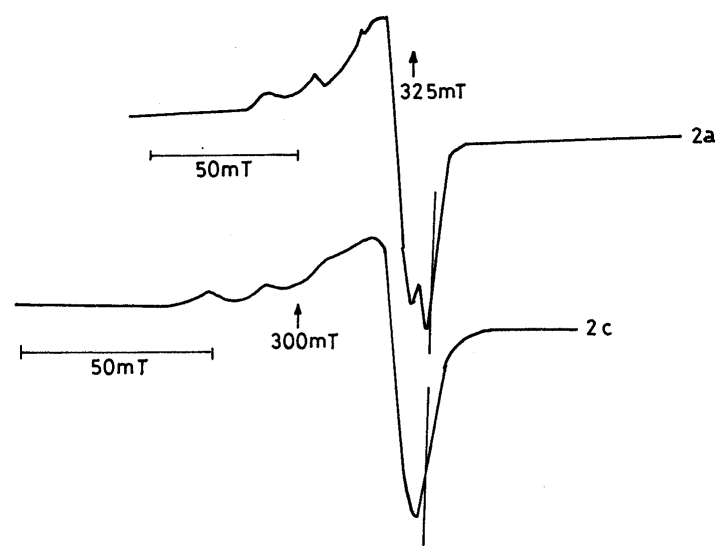

Figure 3. EPR spectrum of acetato bridged $\left[\mathrm{Cu}_{2} \mathrm{~L}^{1}(\mathrm{OAc})_{2}\right] \mathrm{ClO}_{4} \cdot \mathrm{H}_{2} \mathrm{O}$ (2a) and acetato bridged $\left[\mathrm{Cu}_{2} \mathrm{~L}^{3}(\mathrm{OAc})_{2}\right] \mathrm{ClO}_{4} \cdot \mathrm{H}_{2} \mathrm{O}(\mathbf{2 c})$.

We have recorded the EPR spectra for these complexes and the calculated spin Hamiltonian parameters are included in table 2. For these three complexes, the $g_{\perp}$ and $A_{\perp}$ values are slightly lesser than for the 1 and 2 series. EPR spectra for a few nitrite bridged complexes are shown in figure 4 . In one of our previous studies ${ }^{17}$ dealing with hydroxo, acetate and nitrite-bridged complexes, we noticed a substantial decrease in $A$ values for nitrite complexes compared to the other two. That observation has been explained on the basis of a weak interaction between the two copper ions. However, in the present case, we did not notice any such reduction.

Using the spin Hamiltonian parameters, covalency parameters $\left(\alpha^{2}, \alpha^{\prime}, \beta_{1}{ }^{2}\right)$ have been calculated using the standard formula ${ }^{21}$. The equations are

$$
\begin{aligned}
& \alpha^{2}=\left(A_{\|} / 0.036\right)+\left(g_{\|}-2 \cdot 0023\right)+(3 / 7)\left(g_{\perp}-2 \cdot 0023\right)+0.04, \\
& \alpha^{\prime}=\left(1-\alpha^{2}\right)^{1 / 2}+\alpha S, \\
& g_{\|}=2 \cdot 0023-8 \rho\left[\alpha \beta_{1}-(1 / 2) \alpha^{\prime}\left(1-\beta_{1}^{2}\right)^{1 / 2} T(n)\right],
\end{aligned}
$$




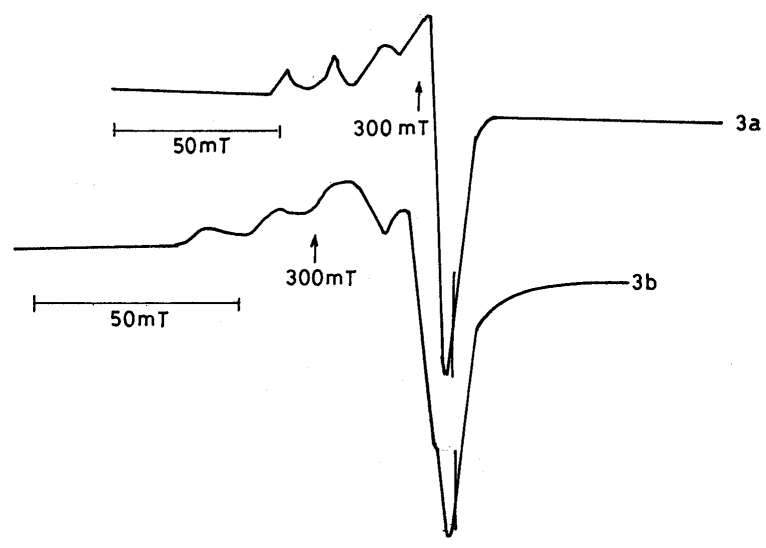

Figure 4. EPR spectrum of nitrito-bridged $\left[\mathrm{Cu}_{2} \mathrm{~L}^{1}\left(\mathrm{NO}_{2}\right)_{2}\left(\mathrm{H}_{2} \mathrm{O}\right)_{2}\right] \mathrm{ClO}_{4} \cdot \mathrm{H}_{2} \mathrm{O}(\mathbf{3 a})$ and nitrito-bridged $\left[\mathrm{Cu}_{2} \mathrm{~L}^{2}\left(\mathrm{NO}_{2}\right)_{2}\left(\mathrm{H}_{2} \mathrm{O}\right)_{2}\right] \mathrm{ClO}_{4} \cdot \mathrm{H}_{2} \mathrm{O}(\mathbf{3 b})$.

Table 3. Optical transition and covalency parameter for $\mathrm{Cu}(\mathrm{II})$ complexes.

\begin{tabular}{|c|c|c|c|c|c|}
\hline Complexes & $\lambda_{\max }(\mathrm{nm})$ & $\alpha^{2}$ & $\alpha$ & $\alpha^{\prime}$ & $\beta_{1}$ \\
\hline $1 \mathrm{a}$ & 636 & 0.791 & 0.889 & 0.524 & 0.80 \\
\hline $1 b$ & 661 & 0.872 & 0.934 & 0.428 & 0.86 \\
\hline 1c & 661 & $0 \cdot 760$ & 0.872 & 0.555 & $0 \cdot 82$ \\
\hline $2 a$ & 680 & 0.821 & 0.906 & 0.491 & 0.92 \\
\hline $2 b$ & 671 & 0.834 & $0 \cdot 913$ & 0.476 & 0.79 \\
\hline $2 c$ & 663 & 0.822 & 0.907 & 0.489 & 0.76 \\
\hline $3 a$ & 658 & $0 \cdot 819$ & 0.905 & 0.493 & 0.76 \\
\hline $3 b$ & 650 & $0 \cdot 844$ & 0.919 & 0.463 & 0.81 \\
\hline $3 c$ & 670 & $0 \cdot 812$ & $0 \cdot 901$ & $0 \cdot 501$ & $0 \cdot 78$ \\
\hline
\end{tabular}

where $\alpha$ denotes the in-plane $\sigma$ bonding, $\alpha^{\prime}$ is normalizing condition on the ground state orbital, $S$ is overlap integral between ground state orbital and normalized ligand orbital, $\beta_{1}{ }^{2}$ is a direct measure of the covalency of the in-plane $\pi$ bonding, $\rho=\lambda_{0} \alpha \beta_{1} / \Delta E$ where $\lambda_{0}$ is spin-orbit coupling constant for the free ion and $\Delta E$ is the transition energy between ${ }^{2} B_{1}$ and ${ }^{2} B_{2}$ states. We can assume $S=0.076, \lambda_{0}=-828 \mathrm{~cm}^{-1}$ if the ligands are oxygen or nitrogen donors. $T(n)$ is a function involving metal-ligand distance, hybridization constant $(n)$ and effective nuclear charges for the ligand $2 s, 2 p$ and the metal $d$ orbitals. $T(n)$ is assumed as $0 \cdot 220^{22}$. Using optical and EPR data, we have calculated the parameters $\alpha^{2}, \alpha^{\prime}$ and $\beta_{1}{ }^{2}$ for all copper complexes and the results are given in table 3 . It is clear from the table that the covalency parameters have a trend similar to that similar trend noticed with the spin Hamiltonian parameters. However complexes $\mathbf{1 b}, \mathbf{2} \mathbf{b}$ and $\mathbf{3 b}$ behave slightly differently from other members of the series.

Since the copper hyperfine values are slightly lower for nitrite-bridged complexes, we can arrange these complexes for the metal-metal interaction roughly in the order

$$
\mathrm{NO}_{2} \geq \mathrm{OAc}>\mathrm{OH} \text {. }
$$


Table 4. Electrospray mass spectral data.

\begin{tabular}{|c|c|c|}
\hline Complex & $\mathrm{m} / \mathrm{z}$ & Peak assignment \\
\hline 1a & $\begin{array}{l}309 \text { (base) } \\
471\left(\mathrm{HL}^{1}\right) \\
597 \\
614 \\
632 \\
865(\mathrm{M})\end{array}$ & $\begin{array}{l}{\left[\mathrm{C}_{20} \mathrm{H}_{25} \mathrm{ON}_{2}\right]^{+}} \\
{\left[\mathrm{C}_{30} \mathrm{H}_{39} \mathrm{ON}_{4}\right]^{+}} \\
{\left[\mathrm{Cu}_{2} \mathrm{~L}^{1}\right]^{+}} \\
{\left[\mathrm{Cu}_{2} \mathrm{~L}^{1}(\mathrm{OH})\right]^{+}} \\
{\left[\mathrm{Cu}_{2} \mathrm{~L}^{1}(\mathrm{OH})\left(\mathrm{H}_{2} \mathrm{O}\right)\right]^{+}} \\
{\left[\mathrm{Cu}_{2} \mathrm{~L}^{1}(\mathrm{OH})\left(\mathrm{H}_{2} \mathrm{O}\right)_{3}\left(\mathrm{ClO}_{4}\right)_{2}\right]^{+}}\end{array}$ \\
\hline $2 a$ & $\begin{array}{l}309 \\
471\left(\mathrm{HL}^{1}\right) \\
597 \\
656 \\
713 \text { (base) } \\
716 \\
755 \\
831(\mathrm{M})\end{array}$ & $\begin{array}{l}{\left[\mathrm{C}_{20} \mathrm{H}_{25} \mathrm{ON}_{2}\right]^{+}} \\
{\left[\mathrm{C}_{30} \mathrm{H}_{39} \mathrm{ON}_{4}\right]^{+}} \\
{\left[\mathrm{Cu}_{2} \mathrm{~L}^{1}\right]^{+}} \\
{\left[\mathrm{Cu}_{2} \mathrm{~L}^{1}\left(\mathrm{CH}_{3} \mathrm{COO}\right)\right]^{+}} \\
{\left[\mathrm{Cu}_{2} \mathrm{~L}^{1}\left(\mathrm{CH}_{3} \mathrm{COO}\right)_{2}\right]^{+}-3 \mathrm{H}^{+}} \\
{\left[\mathrm{Cu}_{2} \mathrm{~L}^{1}\left(\mathrm{CH}_{3} \mathrm{COO}\right)_{2}\right]^{+}} \\
{\left[\mathrm{Cu}_{2} \mathrm{~L}^{1}\left(\mathrm{CH}_{3} \mathrm{COO}\right)\left(\mathrm{ClO}_{4}\right)\right]^{+}} \\
\left.\left[\mathrm{Cu}_{2} \mathrm{~L}^{1}(\mathrm{OAc})_{2}(\mathrm{ClO})_{4}\right)\left(\mathrm{H}_{2} \mathrm{O}\right)\right]^{+}\end{array}$ \\
\hline $3 a$ & $\begin{array}{l}309 \text { (base) } \\
471\left(\mathrm{HL}^{1}\right) \\
535 \\
597 \\
714 \\
760 \\
788 \\
796 \\
841(\mathrm{M})\end{array}$ & $\begin{array}{l}{\left[\mathrm{C}_{20} \mathrm{H}_{25} \mathrm{ON}_{2}\right]^{+}} \\
{\left[\mathrm{C}_{30} \mathrm{H}_{39} \mathrm{ON}_{4}\right]^{+}} \\
{\left[\mathrm{CuL}^{1}\right]^{+}} \\
{\left[\mathrm{Cu}_{2} \mathrm{~L}^{1}\right]^{+}} \\
{\left[\mathrm{Cu}_{2} \mathrm{~L}^{1}\left(\mathrm{ClO}_{4}\right)\left(\mathrm{H}_{2} \mathrm{O}\right)\right]^{+}} \\
{\left[\mathrm{Cu}_{2} \mathrm{~L}^{1}\left(\mathrm{NO}_{2}\right)\left(\mathrm{ClO}_{4}\right)\left(\mathrm{H}_{2} \mathrm{O}\right)\right]^{+}} \\
{\left[\mathrm{Cu}_{2} \mathrm{~L}^{1}\left(\mathrm{NO}_{2}\right)_{2}\left(\mathrm{ClO}_{4}\right)\right]^{+}} \\
{\left[\mathrm{Cu}_{2} \mathrm{~L}^{1}\left(\mathrm{NO}_{2}\right)_{2}\left(\mathrm{ClO}_{4}\right)\left(\mathrm{H}_{2} \mathrm{O}\right)_{3}\right]^{+}} \\
{\left[\mathrm{Cu}_{2} \mathrm{~L}^{1}\left(\mathrm{NO}_{2}\right)_{2}\left(\mathrm{ClO}_{4}\right)\left(\mathrm{H}_{2} \mathrm{O}\right)_{3}\right]^{+}}\end{array}$ \\
\hline
\end{tabular}

The above order is purely logical and based on an approximate approach. This order can be confirmed by studying these systems at low temperatures and single crystal EPR may shed better light on the behaviour of these complexes.

\subsection{Electrospray mass spectra}

Electrospray mass spectral analyses were carried out for the complexes 1a, 2a and 3a. Base peaks for the complexes 1a and 3a occur at $m / z$ 309. This results from the loss of one of the N-phenylpiperizine arms from the ligands and we use this peak as diagnostic for the presence of $\mathrm{N}$-phenylpiperizine arms. At lower mass units (i.e $\mathrm{m} / \mathrm{z}$ less than 470) there are many similarities in the spectrum to that found for the ligand $\mathrm{HL}^{1}$ and these peaks are identified as those from ligand fragmentations. Moreover these complexes show peaks indicative of their binuclear nature along with peaks derived from fragmentations to the mononuclear species. Important peak assignments and their corresponding $\mathrm{m} / \mathrm{z}$ values are given in table 4 . The electrospray mass spectrum of the complex 2a is given in figure 5 .

\section{Conclusions}

We have prepared three new ligands with an $\mathrm{N}_{4} \mathrm{O}$ donor set and their copper complexes. These complexes have some biological significance in bioinorganic chemistry. All the complexes show quasireversible nature of the electron transfer mechanism. The large 

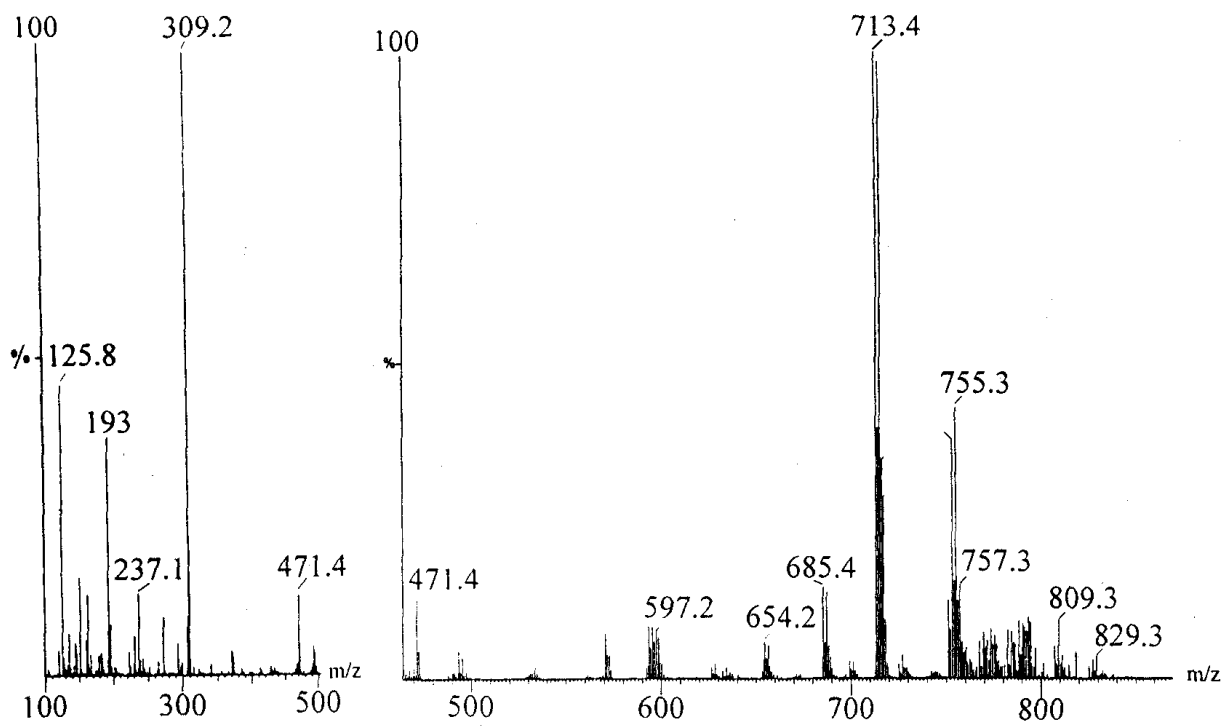

Figure 5. Electrospray mass spectrum of $\left[\mathrm{Cu}_{2} \mathrm{~L}^{1}(\mathrm{OAc})_{2}\right] \mathrm{ClO}_{4} \cdot \mathrm{H}_{2} \mathrm{O}(\mathbf{2 a})$.

$K_{\text {con }}$ values indicate that the addition of the second electron is more difficult. During the course of EPR investigations, we observed that copper hyperfine values are slightly lower for nitrite-bridged complexes. Hence, we can arrange all the complexes based on $\mathrm{M}-\mathrm{M}$ interaction roughly in the order $\mathrm{NO}_{2} \geq \mathrm{OAc}>\mathrm{OH}$. The electrospray mass spectral analysis data indicate the presence of a binuclear core in these complexes.

\section{Acknowledgement}

The authors thank the Council of Scientific \& Industrial Research (CSIR), the University Grants Commission, and the Department of Science \& Technology, New Delhi for financial assistance. RK and RM thank the CSIR for fellowships.

This paper is dedicated to Prof J Subramanian on the occasion of his sixtieth birthday.

\section{References}

1. Fenton D E and Gayda S E 1977 J. Chem. Soc., Dalton Trans. 2109

2. Eduok E E and O'Connor C J 1984 Inorg. Chim. Acta. 85229

3. Mallah T, Boillot M L, Kahn O, Gouteron J, Jeannin S and Jeannin R 1986 Inorg. Chem. 25 3058

4. Sorrel T N, Jameson D L and O'Connor C J 1984 Inorg. Chem. 23191

5. Sorrell T N, O’Connor C J, Anderson O P and Reibenspies J H 1985 J. Am. Chem. Soc. 107 4199

6. Sorrell T N 1989 Tetrahedron 458

7. Jonathan H and Hodgkin 1984 Aust. J. Chem. 372371

8. Grazybowski J D, Merrel F H and Urbach F L 1978 Inorg. Chem. 173078

9. Nakamoto K 1986 Infrared and Raman spectra of inorganic and coordination compounds 4th edn (New York: Wiley) pp 147, 150, 227, 233, 251, 253

10. Hathway B J and Underhill A E 1961 J. Chem. Soc. 3091 
11. Christou G, Perlepes G S P, Libby E, Folting K, Huffan J C, Weeb R J and Hendrickson D N 1990 Inorg. Chem. Rev. 293657

12. Deacon G B and Philips R 1980 J. Coord. Rev. 33227

13. Hitchman M A 1982 Coord. Chem. Rev. 4255

14. Reinen D and Friebel C 1984 Inorg. Chem. 23791

15. Oberhausen K J, Richardson J F, Buchanan R M, McCusker J K, Hendrickson D N and Latour J-M 1991 Inorg. Chem. 301357

16. Lacroix P, Kahn O, Gleizes A, Valade L and Casspix P 1984 Nouv. J. Chim. 8643

17. Sujatha S, Rajendiran T M, Kannappan R, Venkatesan R and Sambasiva Rao P 2000 Indian Acad. Sci. (Chem. Sci.) 1121

18. Creutz C and Taube H 1973 J. Am. Chem. Soc. 951086

19. Morrison W H, Krogsrud S and Hendrickson D N 1973 Inorg. Chem. 121998

20. Gagne R R, Keval C A, Smith T J and Cimolino M C 1979 J. Am. Chem. Soc. 1014571

21. Lorentz D R, Wasson J R, Johnson P R and Thornton D A 1975 J. Inorg. Nucl. Chem. 372297

22. Maki A H and McGarvey B R 1958 J. Chem. Phys. 2931 